\title{
RADIOCARBON IN PARTICULATE MATTER FROM THE EASTERN SUB-ARCTIC PACIFIC OCEAN: EVIDENCE OF A SOURCE OF TERRESTRIAL CARBON TO THE DEEP SEA
}

\section{ELLEN R M DRUFFEL, SUSUMU HONJO, SHEILA GRIFFIN}

Woods Hole Occanographic Institution

Woods Hole, Massachusetts 02543

\author{
and $\mathrm{C} S \mathrm{~S}$ WONG
}

Institute of Ocean Sciences

Sidney, British Columbia, Canada V8L 4B2

\begin{abstract}
Carbon isotope ratios were measured in organic and inorganic carbon of settling particulate matter collected with a sediment trap at Ocean Station " $P$ " in the Gulf of Alaska from March to October, 1983. I)issolved inorganic carbon (DIC) in surface sea water collected during two different seasons in 1984 were analyzed using large gas proportional counters and revealed a minimum seasonal $\Delta^{14} \mathrm{C}$ variation of $14 \%$. Results show that the $\Delta^{14} \mathrm{C}$ of calcium carbonate sedimenting to the decp sea is the same as that measured in surface water DIC. In contrast, particulate organic carbon (POC) had significantly higher $\Delta^{14} \mathrm{C}$ values (by $25-70 \%$ ) than that in surface water DIC. Also, the $\delta^{13} \mathrm{C}$ of the POC was markedly lower than previously reported values from other trap stations and marine particulate matter in general. Results from this study suggest that a significant amount of the POC settling to the deep sea at this pelagic station is of terrestrial origin, not strictly of marine origin as had previously been believed.
\end{abstract}

\section{INTRODUCTION}

It is believed that most of the organic carbon delivered to the deep sea originates as detrital remains of plankton living in the euphotic zone, and falls quickly through the water column (Deuser \& Ross, 1980; Honjo, 1980; Smith \& Baldwin, 1984). However, we know little of the relative importance of other processes, such as 1) transformation reactions of $\mathrm{POC}$ in the water column (Wakeham et al, 1984), 2) the in situ production of POC via chemosynthesis at mid-depth levels in the water column (Karl \& Knauer, 1984), or 3) contribution of POC from sources other than primary productivity in the surface waters (ie, riverine or atmospheric input).

In order to contribute to an understanding of the major processes controlling the flux of particulate carbon in the oceanic water column, we measured carbon isotope ratios $\left({ }^{14} \mathrm{C} /{ }^{12} \mathrm{C}\right.$ and $\left.{ }^{13} \mathrm{C} /{ }^{12} \mathrm{C}\right)$ in sediment trap material collected from the deep Northeast Pacific Ocean. Due to the large difference between the ${ }^{14} \mathrm{C} /{ }^{12} \mathrm{C}$ ratio in the DIC in surface $(+70$ to $85 \%$, Table 1) and deep $(-150$ to $-240 \%$ below $1000 \mathrm{~m}$, Bien, Rakestraw \& Suess, 1965) waters in the Pacific, it is possible to estimate the relative source strengths of marine-derived particulate organic carbon which settles to the deep sea. These data reveal that ${ }^{14} \mathrm{C}$ levels in POC are higher than in the DIC in overlying surface waters. This suggests a non-marine source of organic carbon to the deep sea.

\section{OCEANOGRAPHIC SETTING}

Ocean Station " $\mathrm{P}$ " $\left(50^{\circ} \mathrm{N}, 145^{\circ} \mathrm{W}\right)$ is located in the Northeast Pacific at the convergence of the Dilute Domain from the east and the sub-Arctic Current from the west (Favorite, Dodimead \& Nasu, 1976; Fig 1). The com- 
TABLE 1

Radiocarbon $\left(\Delta^{14} \mathrm{C}\right.$ in $\left.\% 0\right), \delta^{13} \mathrm{C}(\% 0)$, organic $\mathrm{C} / \mathrm{N}$ ratios, salinity $(\% 0)$, and total $\mathrm{CO}_{2}(\mu \mathrm{M})$ measurements of samples collected at Ocean Station " $\mathrm{P}$ "

\begin{tabular}{|c|c|c|c|c|c|c|c|c|}
\hline $\mathrm{WH}^{\#}$ & Type & Colln date & Description & $\mathrm{C} / \mathrm{N}$ & $\delta^{13} \mathrm{C}$ & $\Delta^{14} \mathrm{C}$ & $\mathrm{TCO}_{2}$ & Salinity \\
\hline 317 & Trap & $3 / 20-10 / 5 / 83$ & $<63 \mu \mathrm{POC}$ & 6.93 & -25.0 & $135 \pm 10$ & & \\
\hline 314 & Trap & $3 / 20-10 / 5 / 83$ & $<63 \mu \mathrm{PIC}$ & & 2.7 & $65 \pm 10$ & & \\
\hline 323 & Trap & $3 / 20-10 / 5 / 83$ & $63 \mu-1 \mathrm{~mm}$ POC & 6.84 & -25.0 & $142 \pm 10$ & & \\
\hline 322 & Trap & $3 / 20-10 / 5 / 83$ & $63 \mu-1 \mathrm{~mm}$ PIC & & 2.1 & $67 \pm 10$ & & \\
\hline 319 & Trap & $3 / 20-10 / 5 / 83$ & $>1 \mathrm{~mm}$ POC & 7.13 & -24.5 & $106 \pm 10$ & & \\
\hline 318 & Trap & $3 / 20-10 / 5 / 83$ & $>1 \mathrm{~mm}$ PIC & & -1.0 & $69 \pm 10$ & & \\
\hline 324 & DIC & $4 / 29 / 84$ & surf DIC & & 0.5 & $70 \pm 4$ & 2.068 & 32.582 \\
\hline 325 & DIC & $4 / 30 / 84$ & surf DIC & & 1.2 & $69 \pm 3$ & 2.059 & 32.834 \\
\hline 400 & DIC & $8 / 25 / 84$ & surf DIC & & 2.7 & $84 \pm 3$ & & 32.493 \\
\hline
\end{tabular}

bined effect of these two water sources results in a distinct, low-salinity surface layer. At ca $300 \mathrm{~m}$ depth the sub-Arctic Current system predominates (Favorite, Dodimead \& Nasu, 1976), the source of which is the Northwestern Pacific. The deeper layer $(500 \mathrm{~m})$ is in the Ridge Domain, which is cold, saline, nutrient-rich and oxygen-poor water, largely of southern origin. Sea surface temperature reaches a maximum of $13-14^{\circ} \mathrm{C}$ in late August and a minimum of $4-6^{\circ} \mathrm{C}$ in late March. The depth of the mixed layer is 30 to $40 \mathrm{~m}$ from August to October and 100 to $140 \mathrm{~m}$ from February to April.

Three permanent features make up the salinity structure at Ocean Station "P". First is the upper zone from 0 to $100 \mathrm{~m}(32.6 \%)$, second is the halocline from 100 to $200 \mathrm{~m}$ where salinity increases by $1 \%$, and third is the lower zone where values gradually rise to $34.4 \%$ by $1000 \mathrm{~m}$. Maximum surface salinity occurs in winter, and minimum values are present during August when river runoff from melting snow is greatest. The salinity minimum occurs about two months later than the peaks of coastal and river runoff (Dodimead, Favorite \& Hirano, 1963). There is evidence of warming of the subsurface layers as far west as Station "P" during the El Nino/ Southern Oscillation (ENSO) of 1957-58 (Tabata, 1961).

Horizontal and vertical transport of cold water through the halocline at Ocean Station "P" has been studied by several workers (Tully, 1956; Dodimead, 1961; Tabata, 1961). The base of the halocline $(200 \mathrm{~m})$ is the limit of downward transfer of water from the surface and below this level the transfer of water is undirectionally upward (Tully \& Barber, 1960). The lower zone water is drawn into the upper zone through the halocline, but the fresh water is kept in the halocline and upper zone. Vertical upward transport of water at Ocean Station "P" was found to be in the range of 15 to $20 \mathrm{~m} / \mathrm{yr}$ (Tabata, 1965).

\section{METHODS}

Surface sea water samples from 3m depth were collected in April 1984 and in August 1984 at Ocean Station "P" (Table 1). The DIC in sea water was extracted aboard ship using a closed gas recirculation method described by Linick (1975). Extreme caution was exercised to avoid possible shipboard contamination of the samples by tracer levels of ${ }^{14} \mathrm{C}$ or ${ }^{3} \mathrm{H}$ that may have been used on the ship during previous cruises. All hoses, 


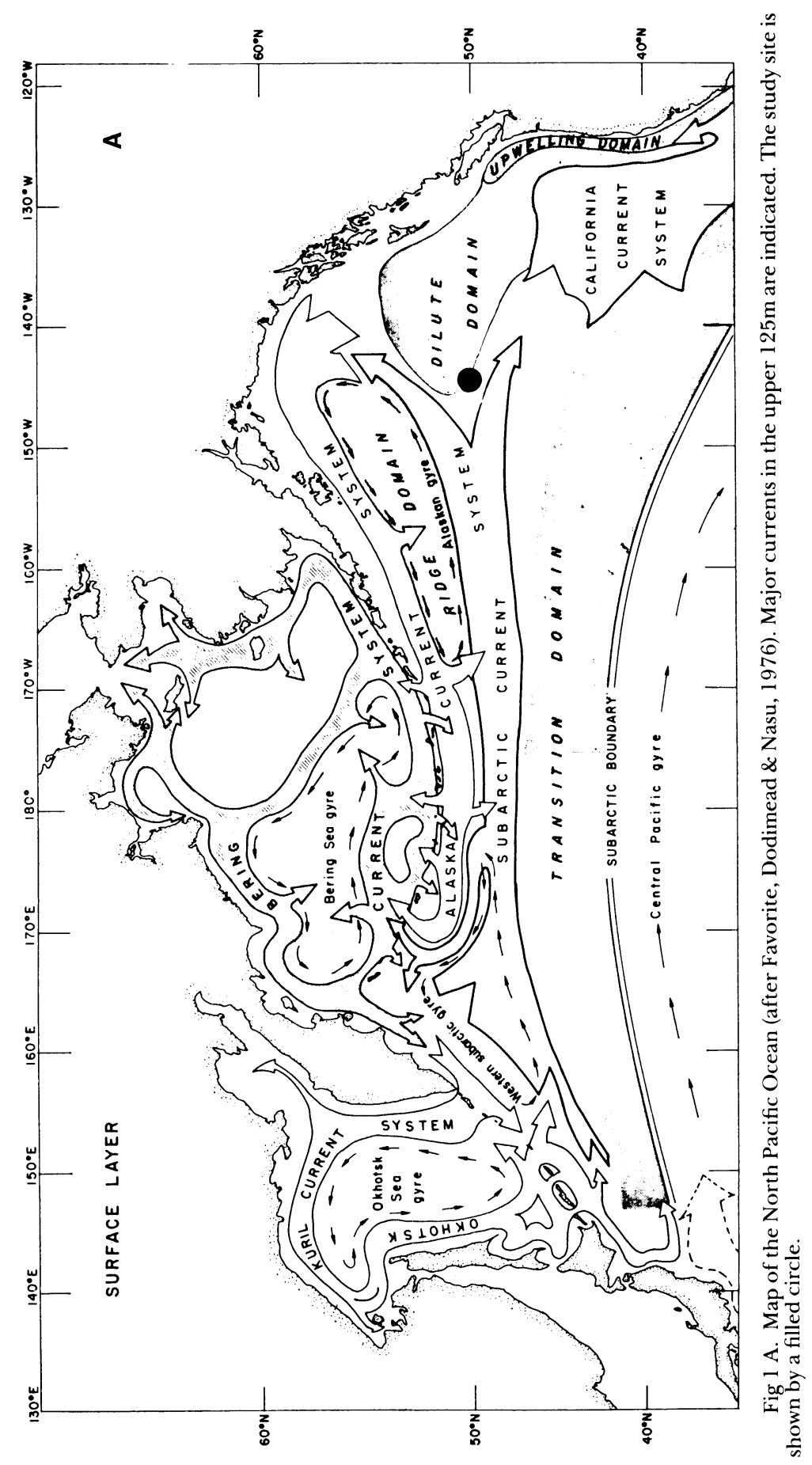




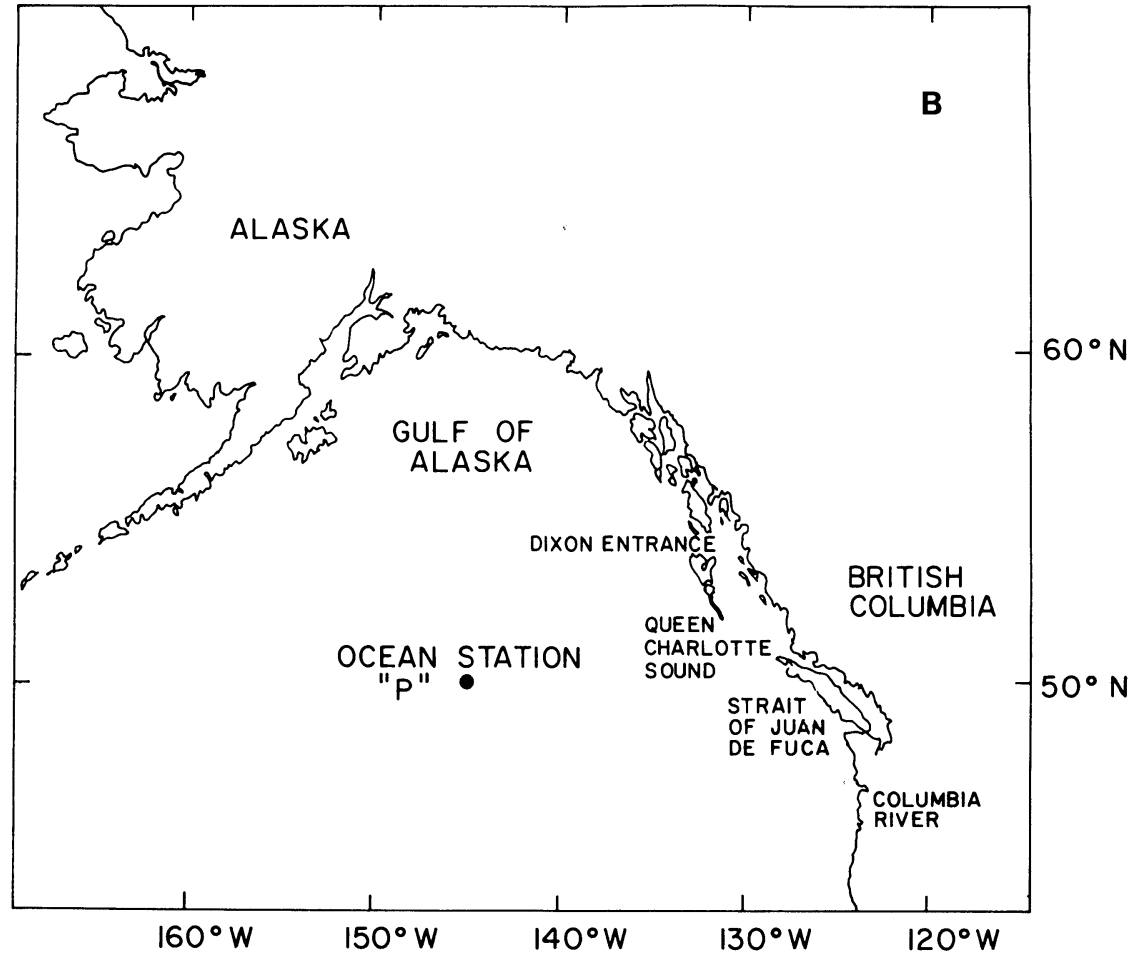

Fig 1 B. Map of the sub-Arctic Northeast Pacific Ocean showing the Ocean Station "p" sampling site. Locations of the four major sources of fresh water to the area are indicated.

pumps, and other supplies were brought aboard and stored on clean surfaces on the deck. Shipboard labs were not used. Gloves were worn during collection and extraction of the samples. To collect the DIC samples, a hose was lowered over the side of the ship. The hose was flushed for a minimum of five minutes before filling a 55-gallon polyethylene drum with sea water. The extraction was started immediately after collection.

The absorber solutions for DIC collection $\left(\mathrm{NH}_{3}\right.$ and $\left.\mathrm{SrCl}_{2}\right)$ were returned to the laboratory, the excess ammonium hydroxide solution was poured off and the remainder of the liquid was heated and pumped away. The strontium carbonate precipitate was then processed according to methods outlined by Griffin and Druffel (1985) to produce purified $\mathrm{C}_{2} \mathrm{H}_{2}$ gas.

A PARFLUX Mark II, single-cup sediment trap (Honjo, Connell \& Sachs, 1980) was deployed at $3800 \mathrm{~m}, 400 \mathrm{~m}$ above the bottom, at Ocean Station "P" from 20 March to 5 October 1983 (199 days). Ca 2 gm of solid $\mathrm{HgCl}_{2}$ was placed in the trap collection cup ( $2 \mathrm{~L}$ volume) prior to deployment to minimize bacterial remineralization of trapped organic matter.

The sediment trap sample was divided into three size fractions, $<63 \mu \mathrm{m}, 63 \mu \mathrm{m}$ to $1 \mathrm{~mm}$, and $>1 \mathrm{~mm}$, using brass sieves. A portion of the 
sample was poured into a $1 \mathrm{~mm}$ sieve and rinsed with distilled water. This was repeated until all of the sample had been separated into two size fractions. The $<1 \mathrm{~mm}$ sample was then sieved with a $63 \mu \mathrm{m}$ sieve. Each sample was filtered through quartz fiber filter paper and rinsed a minimum of two times with distilled water, and dried in an oven $\left(40^{\circ} \mathrm{C}\right)$ overnight. A known amount of material was acidified with $2 \mathrm{~N} \mathrm{HCl}$ under vacuum to convert particulate inorganic carbon (PIC) to $\mathrm{CO}_{2}$. The residue was filtered and rinsed with distilled water. Each sample, which now contained only the organic carbon, was burned in a stream of oxygen to produce $\mathrm{CO}_{2}$.

Each trap sample was counted as $\mathrm{CO}_{2}$ in a copper gas proportional beta counter (volume of $200 \mathrm{cc}$ ) for 3 6-day periods. DIC samples were counted as $\mathrm{C}_{2} \mathrm{H}_{2}$ in each of 2 quartz counters (volumes of 0.75 and $1.5 \mathrm{~L}$ ) for 3 2-day periods. Each $\Delta^{14} \mathrm{C}$ measurement was corrected for isotope fractionation to a $\delta^{13} \mathrm{C}$ of $-25 \%$ relative to $\mathrm{PDB}-1$, and for decay since the time of collection to $\mathrm{AD} 1950$. The ${ }^{13} \mathrm{C} /{ }^{12} \mathrm{C}$ ratio for each sample was measured using a VG Micromass $602 \mathrm{E}$ mass spectrometer.

\section{RESULTS}

Inorganic carbon flux was calculated from the $\mathrm{CO}_{2}$ yield of the acidification procedure and organic carbon flux from $\mathrm{C}: \mathrm{H}: \mathrm{N}$ analyses. We calculated an average carbonate flux of $2.2 \mathrm{gC} / \mathrm{m}^{2} / \mathrm{yr}$, organic carbon flux of $3.2 \mathrm{gC} / \mathrm{m}^{2} / \mathrm{yr}$, and a total mass flux of $64 \mathrm{gC} / \mathrm{m}^{2} / \mathrm{yr}$. These results are ca $20 \%$ lower than those obtained from separate trap experiments at Station "P" during the same time period (Honjo, 1984). The flux was much higher

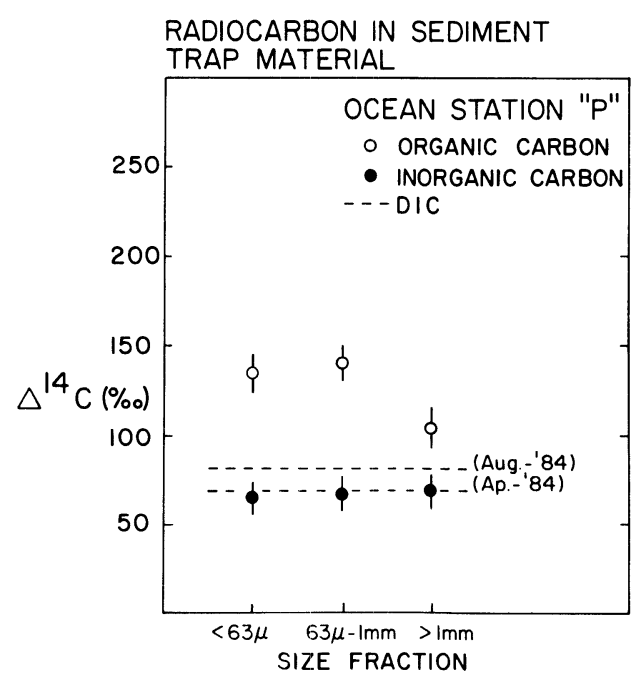

Fig $2 .{ }^{14} \mathrm{C}$ measurements of sediment trap material collected at $3800 \mathrm{~m}$ at Ocean Station "P" (March 20 to Oct 5, 1983). Individual analyses were performed on three size fractions $(<63 \mu, 63 \mu-1 \mathrm{~mm},>1 \mathrm{~mm})$, on both the inorganic and organic carbon. The range of $\Delta^{14} \mathrm{C}$ values in surface ocean water DIC, collected during April and Aug 1984, is also shown. 
during the ENSO event of 1982-83 than during other years (Honjo, 1984; Wong, ms).

${ }^{14} \mathrm{C}$ measurements of DIC in sea water and of POC and PIC in trap material are listed in Table 1 and plotted in Figure 2. $\Delta^{14} \mathrm{C}$ results of two seawater DIC samples taken on consecutive days in April 1984 were identical $\left(70 \pm 4 \%\right.$ and $69 \pm 3 \%$ ). During August 1984 , the $\Delta^{14} \mathrm{C}$ of a single DIC sample was $84 \pm 3 \%$. These limited data suggest that the seasonal ${ }^{14} \mathrm{C}$ variation at this location is at least $14 \%$, probably the result of changes in the depth of the mixed layer. Broecker and Peng (1980) reported a seasonal variation of $35 \%$ in GEOSECS $\Delta^{14} \mathrm{C}$ data in the surface waters of the subtropical North Atlantic gyre. The $\Delta^{14} \mathrm{C}$ values were highest during the summer when the depth of the mixed layer was only $50 \mathrm{~m}$, and the bomb ${ }^{14} \mathrm{C}$ entering the surface ocean from the atmosphere was concentrated into a small volume. During winter, the mixed layer was deeper (150 to $200 \mathrm{~m})$, causing $\Delta^{14} \mathrm{C}$ values to drop an estimated $35 \%$.

The $\Delta^{14} \mathrm{C}$ in all three size fractions of PIC in the sediment trap material (range 67 to $70 \% 0$ ) are statistically the same as in DIC in surface seawater (Table 1). This indicates that biogenic calcium carbonate in particles settling to the deep sea have formed recently in the euphotic zone. However, all three of the organic carbon samples are significantly higher in ${ }^{14} \mathrm{C}$ activity (range 108 to $143 \%$ ) than the DIC or PIC samples.

The $\delta^{13} \mathrm{C}$ values from the three organic carbon samples range from $-25.0 \% 0$ ( $<63 \mu \mathrm{m}$ fraction) to $-24.5 \% 0$ ( $>1 \mathrm{~mm}$ fraction) (Table 1$)$. These values are depleted in $\delta^{13} \mathrm{C}$ by ca $2-4 \%$ with respect to typical marine organic carbon (Williams \& Gordon, 1970; Sackett et al, 1965; Rau, Sweeney \& Kaplan, 1982).

\section{DISCUSSION}

Our $\delta^{13} \mathrm{C}$ results $(-24.5$ to $-25.0 \%)$ indicate that the POC collected at Ocean Station " $\mathrm{P}$ " is significantly depleted in ${ }^{13} \mathrm{C}$ relative to sediment trap samples collected at depth from the Sargasso Sea $(-20.7$ to $-21.4 \%$ ) and the equatorial Atlantic (-21.1\%) (Deuser \& Ross, 1980; Honjo, 1980). Even plankton $\delta^{13} \mathrm{C}$ values that have been found to decrease with increasing latitude (Rau, Sweeney \& Kaplan, 1982) are not as low as our data from Ocean Station "P". This depletion may be the result of several factors. First, if there had been an unusually high concentration of marine lipids ( $>50 \%$ ) the $\delta^{13} \mathrm{C}$ values of which average -26 to $-29 \%$ (Sackett $e t a l$, 1965, 1974; Degens et al, 1968), then the $\delta^{13} \mathrm{C}$ would be low. However, in a study of sediment trap material from several temperate and tropical locations, Wakeham et al (1984) report that only 1 to $10 \%$ of the total POC flux to the deep sea is lipid carbon. McAllister, Parsons \& Strickland (1960) measured only small amounts of lipid (5 to 10\%) in POC filtered from water in the upper $1000 \mathrm{~m}$ at Ocean Station "P". These data indicate that lipid contents of POC falling to the deep sea at Ocean Station "P" could not account for the ${ }^{13} \mathrm{C}$ depletion that we observe in the trap material.

Second, if there had been a significant contribution of chemosynthetically-derived POC ( -30 to $-32 \%$ at hydrothermal vents, Rau, Sweeney \& Kaplan, 1982; Williams et al, 1981) produced at depth in the water column 
(Karl \& Knauer, 1984), then the $\delta^{13} \mathrm{C}$ of the POC would be low. However, if this were the case, the ${ }^{14} \mathrm{C}$ would also be depleted with respect to the surface values, not enriched as our results show (Fig 2).

Thus, it is difficult to invoke a marine source of organic carbon, given our low $\delta^{13} \mathrm{C}$ results. Instead, it is conceivable that a significant amount of carbon is of terrestrial origin, which has values of -25 to $-27 \%$.

There are three possible explanations for the high $\Delta^{14} \mathrm{C}$ values. First, it is possible that the POC reflects slightly higher $\Delta^{14} \mathrm{C}$ values (by $\sim 50 \%$ ) that were present in the surface ocean at Ocean Station " $P$ " 10 to 15 years earlier (Fig 3). This is unlikely, however, as this would suggest that the transport rate of large, organic-rich particles to the deep sea is a decade or more, much longer than other estimates (for a summary, see Honjo, 1984). Even if the transport time was this long, the integrated $\Delta^{14} \mathrm{C}$ value of the particulate matter in the water column would not be as high as that range reported here for the POC.

Second, contamination by tracer levels of ${ }^{14} \mathrm{C}$ is unlikely, as extensive precautions were taken to avoid all contact with surfaces aboard ship and at all land-based locations. Besides, if the sample had been contaminated, we would expect a wider range in $\Delta^{14} \mathrm{C}$ values than the ones we obtained. The sample could reflect tracer levels of ${ }^{14} \mathrm{C}$ (24 millicuries) that were dumped into the surface ocean after productivity measurements were made aboard the $R / V$ Thompson in June 1983 ( $\mathrm{N}$ Welchmeyer, pers commun, April 1985). As all of the dump sites were located several kilometers northeast of the sediment trap location, and the sediment trap was upstream of surface

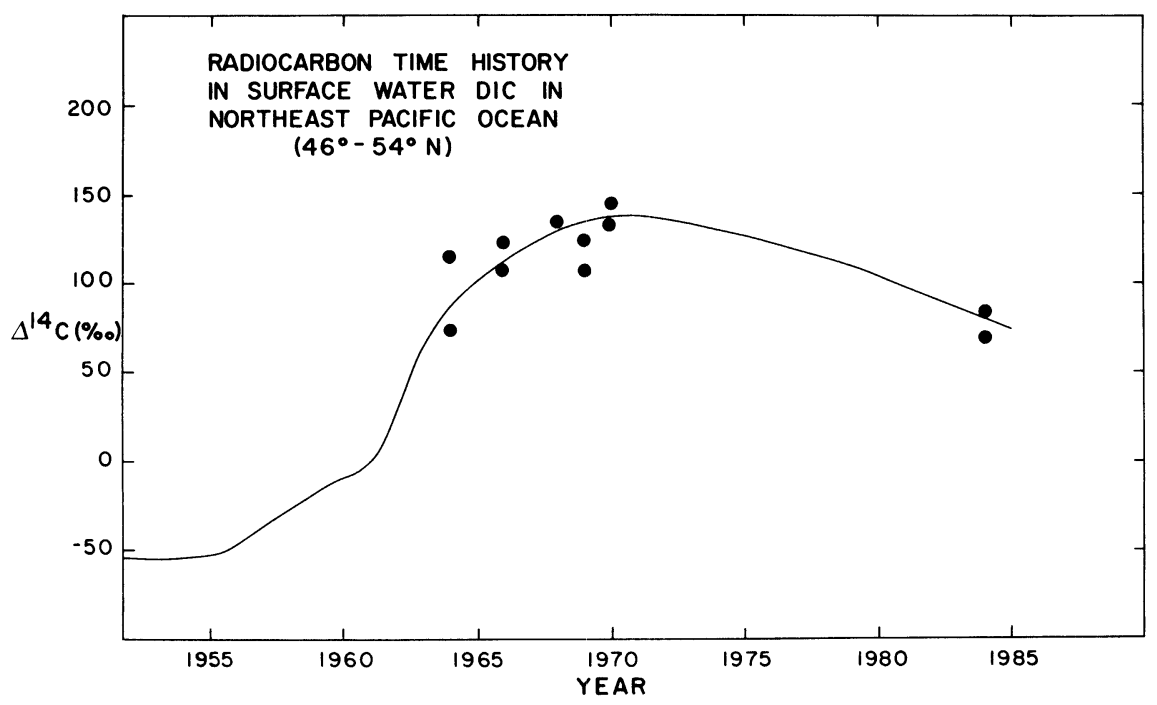

Fig $3 .{ }^{14} \mathrm{C}$ time history in the surface waters of the Northeast Pacific Ocean. Data $(\cdot)$ were obtained from analyses of DIC in surface sea water (Linick, 1975). Radiocarbon measurements made in banded corals from the Hawaiian Islands (Druffel, 1986) were used to construct the curve. 
water movement with respect to the dump sites, we are reasonably certain that the trap was free of contaminated particulate carbon that had been fixed at the surface near the dump sites. Besides, if the trap material were contaminated, we would expect both PIC and POC to contain similar ${ }^{14} \mathrm{C}$ levels, and this was not observed.

It is thus difficult to explain the ${ }^{14} \mathrm{C}$ data strictly in terms of marine sources of POC. This brings us to our third and most likely explanation, $i e$, there may be a significant amount of terrestrially-derived carbon falling to the deep sea at Ocean Station "P". As ${ }^{14} \mathrm{C}$ levels in living terrestrial carbon reservoirs have always exceeded those in marine carbon reservoirs during post-bomb times (Cain \& Suess, 1976; Druffel \& Suess, 1983), this would explain the high $\Delta^{14} \mathrm{C}$ results.

Our $\Delta^{14} \mathrm{C}$ values in POC ranged from 108 to $143 \%$, higher by 25 to $70 \%$ than $\Delta^{14} \mathrm{C}$ in the surface water DIC. If terrestrial carbon is indeed the source of ${ }^{14} \mathrm{C}$-enriched POC, then a mass balance calculation reveals that $30 \pm 15 \%$ of the organic carbon present in our trap is of terrestrial origin (where the $\Delta^{14} \mathrm{C}$ of this end-member is $27 \%$, Hedges $e t$ al, 1986). The $\delta^{13} \mathrm{C}$ signature of organic matter produced on land is lower than that produced in the ocean, which fits the trend of our trap $\delta^{13} \mathrm{C}$ values. If we consider that $\delta^{13} \mathrm{C}$ in the trap POC is higher by ca 2.5\% than marine-derived POC at this latitude (average of $-22 \pm 2 \%$; Rau, Sweeney \& Kaplan, 1982; McConnaughey \& McRoy, 1979), and if we assume that terrestrial POC is $-26.0 \pm$ $1 \%$, then a terrestrial carbon contribution of ca $50 \pm 30 \%$ of the total flux to the deep sea is suggested. The higher $\delta^{13} \mathrm{C}$ and lower $\Delta^{14} \mathrm{C}$ values for the $\mathrm{POC}$ in the $>1 \mathrm{~mm}$ size fraction suggest that a higher percentage of marine-derived organic carbon was present in the large sinking particles, which consisted primarily of pteropods and fecal pellets. Also, the organic $\mathrm{C} / \mathrm{N}$ ratios measured in the trap material (6.8 to 7.1) can be obtained from a mixture of $17 \%$ terrestrial material $(\mathrm{C} / \mathrm{N}=15)$ and $83 \%$ marine plankton $(\mathrm{C} / \mathrm{N}=5.5)$. The relative percentage of terrestrial carbon in the total POC flux at the surface is likely to be less, however, as Gagosian, Nigrelli \& Volkman (1983) have shown that sterols of terrestrial origin are more resistant to degradative processes in the marine environment than is marine-derived material.

There are two mechanisms that could be responsible for transport of terrestrial carbon to the deep sea: atmospheric deposition and river runoff. Zafiriou et al (1985) reported that the total organic carbon flux from the atmosphere to the ocean near Enewetak atoll $\left(12^{\circ} \mathrm{N}, 163^{\circ} \mathrm{E}\right)$ was $600 \mathrm{mgC} /$ $\mathrm{m}^{2} / \mathrm{yr}$ and was due mainly to rainwater scavenging. When compared with our flux into the sediment trap $\left(5.4 \mathrm{gC} / \mathrm{m}^{2} / \mathrm{yr}\right)$, an atmospheric contribution of this magnitude would be small $(\sim 13 \%)$, but not negligible. Moore and Heath (1982) reported wind-blown quartz concentrations of ca $10 \%$ (g $\mathrm{dw}$ ) in the sediment underlying our collection site in the Northeast Pacific Ocean, which indicates substantial atmospheric input of particulate matter to the ocean. It is not likely, however, that atmospheric processes constitute the major source of terrestrially-derived organic carbon to the Ocean Station "P" site.

Instead, we propose that the primary source of terrestrial carbon to 
the Ocean Station "P" site is via riverine input. This source may be particularly important during the 1982-83 ENSO event, as Royer (1985) observed warmer, fresher coastal waters in the Northeast Pacific during this period, which could indicate an increase in the flow of the Alaska Coastal Current. It is possible that rivers discharge small, neutrally buoyant particles containing bomb ${ }^{14} \mathrm{C}$ that fall to the deep sea and are degraded before deposition to the surface sediments. Degradation of this material is necessary as Hedges \& Mann (1979) have reported an absence of lignin in marine sediments from this area.

During a study of the primary productivity at Ocean Station ' $P$ ' in the summer of 1959, McAllister, Parsons and Strickland (1959) collected particulate organic material from 0 to $1000 \mathrm{~m}$ in the water column. They found that approximately one-half of the POC was carbohydrate carbon. Upon microscopic examination, they revealed that "a considerable portion [of the POC] was composed of fibrous material of irregular dimensions which had the appearance and gave a positive stain for cellulose." They concluded that most of the carbohydrate in the samples was cellulose fiber of terrestrial origin; this constituted about one-third of the POC by weight.

The most important conclusion from our study is that it appears that a significant amount of terrestrially-derived POC, which has been observed in the surface waters (McAllister, Parsons \& Strickland, 1959), may actually be delivered to the deep sea. However, we do not know whether it has been altered by chemical or biological processes as carbon isotopes cannot determine this.

Studies are ongoing to characterize the source of terrestrial carbon in the trap material. Using the optical brightner calcofluor as an indicator for cellulose, abundant cellulose spheres (10-20 $\mu \mathrm{m}$ in diameter) were found associated with dinoflagellates and dinoflagellate debris, with a background of tiny pieces of uncharacterized material. Little evidence of fibrous cellulose was detected, however. Upon acetolysis of the trap material, we found small (3 to $10 \mu \mathrm{m})$ unidentified brown particles that were abundant $(\sim 10 \%)$. Also found within this sample were Alnus (alder) and Salix (willow) pollen grains; alder is common in British Columbia. It is likely that pollen grains, which have been observed in other deep-sea sediment traps (Hinja, Sieburth \& Heath, 1979), are supplied to the Alaskan gyre circulation via fluvial transport, and thus, are responsible at least in part for the high $\Delta^{14} \mathrm{C}$ and low $\delta^{13} \mathrm{C}$ values found in our POC samples.

In summary, our studies show that POC falling to the deep sea in the northeast sub-Arctic Pacific region is depleted in ${ }^{13} \mathrm{C}$ and enriched in ${ }^{14} \mathrm{C}$ in such a manner that suggests a source of carbon that is terrestrially-derived, probably from the numerous surrounding rivers during the late summer. ${ }^{14} \mathrm{C}$ levels are not depleted in the trap POC, as would have been expected had there been significant transport of sediment from the shelf or chemosynthetic production of POC at depth in the water column.

ACKNOWLEDGMENTS

We are grateful to Al Bradshaw, John Frankenthal, Danuta Kaminski, Steve Manganini, and Abbey Spencer for their technical expertise. We 
thank Lloyd Keigwin for the use of the mass spectrometer and C Eben Franks for his help with its operation. We are grateful to Tom Ager, Don Anderson, Dean Jacobson, Mary Silver, and Kozo Takahashi for their microscopic examinations of the trap material. We thank Steve Emerson, Robert Gagosian, John Hedges, Susan Henrichs, Lloyd Keigwin, Cindy Lee, Dan McCorkle, Ann McNichol, Greg Rau, Stuart Wakeham, and Pete Williams for helpful discussions and reviews of the manuscript. We are grateful to Molly Lumping for typing the manuscript. This work was supported by the National Science Foundation through grants OCE83-15260, OCE84-16632 and OCE83-09024. This is Woods Hole Oceanographic Institution No. 6053.

\section{REFERENCES}

Bien, G S, Rakestraw, N W and Suess, H E, 1965, Radiocarbon in the Pacific and Indian Oceans in its relation to deep water movements: Limnol and Oceanog, v 10, p R25-36.

Broecker, W S and Peng, T S, 1980 , Seasonal variability in the ${ }^{14} \mathrm{C} /{ }^{12} \mathrm{C}$ ratio for surface ocean water: Geophys Research Letters, v 7, p 1020-1022.

Cain, W F and Suess, H E, 1976, Carbon-14 in tree rings: Jour Geophys Research, v 81, p 3688-3694.

Degens, E T, Behrendt, M, Gotthardt, B and Reppmann, E, 1968, Metabolic fractionation of carbon isotopes in marine plankton-II. Data on samples collected off the coasts of Peru and Ecuador: Deep-Sea Research, v 15, p 11-20.

Deuser, W G and Ross, E H, 1980, Seasonal change in the flux of organic carbon to the deep Sargasso Sea: Nature, v 283, p 364-365.

Dodimead, A J, 1961, Some features of the upper zone in the sub-Arctic Pacific Ocean: Internatl North Pacific Fish Comm Bull, v 3, p 11-24.

Dodimead, A J, Favorite, F and Hirano, T, 1963, Salmon of the North Pacific Ocean-Part II-Review of the oceanography of the sub-Arctic Pacific region: Internatl North Pacific Fisheries Comm Bull, v 13, 195 p.

Druffel, E R M and Suess, H, 1983, On the radiocarbon record in banded corals: Exchange parameters and net transport of ${ }^{14} \mathrm{CO}_{2}$ between atmosphere and surface ocean: Jour Geophys Research, v 88, no. C2, p 1271-1280.

Druffel, E R M, 1986, Seasonal variability of radiocarbon in surface waters of the tropical Pacific: Implications for upper ocean circulation: Jour Marine Research, in press.

Favorite, F, Dodimead, A J and Nasu, A J, 1976, Oceanography of the sub-Arctic Pacific region, 1961-1970: Internatl North Pacific Fisheries Comm Bull, v 33, 187 p.

Griffin, S M and Druffel, E R M, 1985, Woods Hole Oceanographic Institution Radiocarbon Laboratory: Sample treatment and gas preparation: Radiocarbon, v 27, no. 1, p 43-51.

Hedges, I I and Mann, D C, 1979, The lignin geochemistry of marine sediments from the southern Washington coast: Geochim et Cosmochim Acta, v 43, p 1809-1818.

Hedges, K O, Ertel, J R, Quay, P D, Grootes, P M, Richey, J E, Devol, A H, Farwell, G W, Schmidt, F G and Salati, E, 1986, Organic carbon-14 in the Amazon river system: Science, v 231, p 1129-1131.

Hinja, K R, Sieburth, J McN and Heath, G R, 1979, The supply and use of organic material at the deep-sea floor: Jour Marine Research, v 37, p 557-579.

Honjo, S, Connell, J and Sachs, P, 1980, Deep-ocean sediment trap: design and function of PARFLUX Mark II: Deep-Sea Research, v 27, p 745-753.

Honjo, $\mathrm{S}, 1980$, Material fluxes and modes of sedimentation in the mesopelagic and bathypelagic zones: Jour Marine Research, v 38, p 53-97.

- 1982, Seasonality and interaction of biogenic and lithogenic particulate flux at the Panama Basin: Science, v 218, p 883-884.

1984, A study of ocean fluxes in time and space by bottom-tethered sediment trap arrays: A recommendation, in Global ocean flux study, Sept 10-14, 1984, Proc: Washington, DC, Natl Acad Press, p 306-324.

Karl, D M and Knauer, G A, 1984, Detritus-microbe interactions in the marine pelagic environment: Selected results from the VERTEX experiment: Bull Marine Sci, v 35, no. 3, p $550-565$.

Linick, T W, (ms) 1975, Uptake of bomb-produced carbon-14 by the Pacific Ocean: Ph D dissert, Univ California San Diego.

McAllister, C D, Parsons, T R and Strickland, J D H, 1959, Data record: Oceanic fertility and productivity measurements at Station "P" July and August 1959: Fish Research Bd Canada MS Rept Ser (Oceans \& Limnol) no. 55. 
McConnaughey, T and McRoy, C P, $1979,{ }^{13} \mathrm{C}$ label identifies eelgrass (Zostera marina) carbon in an Alaskan estuarine food web: Marine Biology, v 53, p 263-269.

Moore, T and Heath, R, 1982, Sea floor sampling techniques, in Riley, J P and Chester, R, eds, Chemical oceanog, 2nd ed, vol 7: London, Academic Press, p 75-126.

Ostlund, H G and Stuiver, M, 1980, GEOSECS Pacific radiocarbon: Radiocarbon, v 22, no. 1, p 25-53.

Rau, G H, Sweeney, R E and Kaplan, I R, 1982, Plankton ${ }^{13} \mathrm{C} /{ }^{12} \mathrm{C}$ ratio changes with latitude: differences between northern and southern oceans: Deep-Sea Research, v 29, no. 8A, p 1035-1039.

Royer, T C, 1985, Coastal temperature and salinity anomalies in the Northern Gulf of Alaska, 1970-84, in Wooster, W S and Fluharty, D L, eds, El Nino North: Washington Sea Grant Program, Univ Washington, Seattle, p 107-115.

Sackett, W M, Eadie, B J and Exner, M E, 1974, Stable isotope composition of organic carbon in recent Antarctic sediments, in Tissot, B and Bienner, F, eds, Advances in organic geochemistry 1973: Paris, Editions Tech, p 661-671.

Sackett, W M, Eckelmann, W R, Bender, ML and Be, A W H, 1965, Temperature dependence of carbon isotope composition in marine plankton and sediments: Science, v 148, p 235237.

Smith, K L and Baldwin, R J, 1984, Seasonal fluctuation in community oxygen consumption: Central and eastern North Pacific: Nature, v 307, p 624-626.

Tabata, S, 1961, Temporal changes of salinity, temperature and dissolved oxygen content of the water at Station "P" in the northeast Pacific Ocean, and some of their determining factors: Jour Fish Research Bd Canada, v 18, no. 6, p 1073-1124.

1965 , Variability of oceanographic conditions at Ocean Station "P" in the northeast Pacific Ocean: Trans Royal Soc Canada, v 3, no. 4, 3, p 367-418.

Tully, J P, 1956, Some characteristics of sea water structure, in Pacific Sci Cong, 8th, Proc: Phillipines, v 3, p 643-662.

Tully, J P and Barber, F G, 1960, An estuarine analogy in the sub-Arctic Pacific Ocean: Jour Fish Research Bd Canada, v 17, no. 1, p 91-112.

Wakeham, S G, Lee, C, Farrington, J W and Gagosian, R B, 1984, Biogeochemistry of particulate organic matter in the oceans: results from sediment trap experiments: Deep-Sea Research, v 31, no. 5, p 509-528.

Williams, P M, Smith, K L, Druffel, E R M and Linick, T W, 1981, Dietary carbon sources of mussel and tubeworm from Galapagos hydrothermal vent determined from tissue ${ }^{14} \mathrm{C}$ activity: Nature, $v$ 292, p 448-449.

Williams, P M and Gordon, L, 1970, Carbon-13:carbon-12 ratios in dissolved and particulate organic carbon in the sea: Deep-Sea Research, v 17, p 19-27.

Zafiriou, O C, Gagosian, R B, Peltzer, E T and Alford, J B, 1985, Air-to-sea fluxes of lipids at Enewetak Atoll: Jour Geophys Research, v 90, no. D1, p 2409-2423. 